DOI $10.15421 / 4220002$

УДК 539.3

В. М. Бистров, канд. фріз.-мат. наук, В. А. Декрет, д-р фріз.-мат. наук, В. С. Зеленський, канд. фоз.-мат. наук

\title{
ВТРАТА СТІЙКОСТІ КОМПОЗИТНОГО МАТЕРІАЛУ, СЛАБКОАРМОВАНОГО ПРИПОВЕРХНЕВИМИ КОРОТКИМИ ВОЛОКНАМИ
}

Із застосуванням основних співвідношень тривимірної лінеаризованої теорії стійкості в рамках моделі кусково-однорідного середовища досліджено втрату стійкості композитного матеріалу, слабкоармованого короткими волокнами поблизу вільної плоскої граничної поверхні. 3'ясовано залежність форм втрати стійкості у структурі композитного матеріалу від розташування волокон відносно вільної поверхні та відстані між сусідніми волокнами. Для числового розв'язку задачі використано метод сіток на основі модифікованого варіаційно-різницевого підходу.

Ключові слова: приповерхневі короткі волокна; фрорма втрати стійкості; кусково-однорідна модель; тривимірна лінеаризована теорія стійкості; числовий підxid.

Вступ. Одним із можливих механізмів руйнування односпрямованих композитних матеріалів (КМ) при стисканні вздовж напрямку армування $€$ втрата стійкості армуючих шарів і волокон. Цей механізм може мати характер втрати стійкості у внутрішній структурі КМ або приповерхневої втрати стійкості у структурі КМ з фрормами втрати стійкості, згасаючими при віддаленні від поверхні КМ.

Дослідження приповерхневої втрати стійкості проводиться за двома напрямками. Перший напрямок стосується дослідження втрати стійкості у структурі матеріалу біля вільної граничної поверхні, другий - біля завантаженої поверхні. Як правило, явище приповерхневої нестійкості передує внутрішній нестійкості. У зв'язку з цим її дослідження дозволяє встановити мінімальне значення критичних параметрів навантаження, при яких може відбутися втрата несучої здатності у приповерхневих шарах композитного матеріалу або у шарах біля завантаженої поверхні. При дослідженні цієї проблеми прийнято моделювати композитні матеріали, що розглядаються, напівобмеженим тілом регулярної або нерегулярної структури з подальшим задовільненням умов загасання досліджуваних фракторів на нескінченності.

Одним із найбільш точних підходів при розгляді вказаної проблеми є застосування тривимірної лінеаризованої теорії стійкості деформівних тіл (ТЛТСДТ) [3, 7] в рамках моделі кусково-однорідного середовища. Огляд відповідних результатів, для КМ, армованих неперервними ком-

() В. М. Бистров, В. А. Декрет, В. С. Зеленський, 2020 
понентами, при стисканні паралельно вільній поверхні представлений в $[4,13]$. Окремі результати, які відносяться до втрати стійкості КМ біля завантаженої поверхні, наведені у $[1,15]$. Результати дослідження стійкості армованих короткими волокнами КМ на основі моделі "коротких волокон" представлені в [5, 9-11]. Явище приповерхневої втрати стійкості композитного матеріалу, слабкоармованого короткими волокнами поблизу вільної граничної поверхні в [14] розглянуто для моделі одного приповерхневого волокна у напівнескінченній матриці.

У даній роботі розглядається випадок двох взаємодіючих приповерхневих волокон у слабкоармованому КМ при повздовжньому стисканні. Дослідження виконується в рамках плоскої деформації, коли розглядається поздовжній перетин волокнистих матеріалів, що проходить через вісь волокон, які лежать в одній площині. Правомірність допущення про те, що при дослідженні втрати стійкості у структурі композиту односпрямований волокнистий композит можна моделювати плоскою задачею для шаруватого композиту, зокрема, обґрунтовано в [6] шляхом порівняльного аналізу результатів розв'язання плоскої і просторової задач стійкості для випадку одного волокна у нескінченній матриці. Складність отримання аналітичних розв'язків для задач зазначеного класу передбачає використання сучасних числових методів. Для числового розв'язку розглянутих задач у даній роботі використовується метод сіток на основі модифікованого варіаційно-різницевого підходу [2, 12]. Як приклад застосування тривимірної скінченно-елементної моделі при дослідженні впливу вільної поверхні на втрату стійкості у структурі армованих неперервними волокнами композитах можна навести результати [16].

Постановка задачі. Постановка задачі відповідає основній концепції, на якій базується дослідження механізмів руйнування КМ при стисканні вздовж напрямку армування. У [8], ця концепція сформульована наступним чином. "У разі композитних матеріалів, які моделюються у континуальному наближенні ортотропними матеріалами, при стисканні вздовж осей симетрії властивостей матеріалів початковим етапом (стартом) руйнування є втрата стійкості у внутрішній структурі композитів (внутрішня нестійкість) або в приповерхневих шарах внутрішньої структури композиту (приповерхнева нестійкість). Поширення руйнування при цьому визначається поведінкою збурень у рамках вживаної (порівняно наближеною або досить строгою) теорії стійкості та починається біля макро- і мікронеоднорідностей. Теоретичною межею міцності при стисканні і теоретичним значенням граничного вкорочення $€$ величина критичного навантаження і величина критичного вкорочення, обчислені у рамках вживаної теорії стійкості." У даній роботі такою теорією $€$ ТЛТСДТ у рамках другого варіанту теорії малих докритичних деформацій $[3,7]$. В залежності від відстані між волокнами та вільною поверхнею механізми руйнування можуть бути пов'язані як із внутрішньою втратою стійкості, так і з приповерхневою нестійкістю КМ.

Розглядається випадок, коли КМ вважається слабкоармованим та має нерегулярну структуру. Це припущення дозволяє розглядати розра- 
хункову схему для двох послідовно розміщених приповерхневих волокон у напівнескінченній матриці (рис. $1, a)$, яка включає рівняння лінійної теорії пружності і рівняння ТЛТСДТ при неоднорідному докритичному стані та граничні умови, які відповідають розрахунковій області $\bar{\Omega}=\left\{\left(x_{1}, x_{2}\right) \mid-l_{1} / 2 \leq x_{1} \leq l_{1} / 2 ;-l_{2} \leq x_{2} \leq 0\right\}$ для стану плоскої деформації у площині $O x_{1} x_{2}$. Одна із сторін цієї області співпадає з вільною граничною поверхнею. Розміри розрахункової області визначається в результаті обчислювального експерименту таким чином, щоб на сторонах прямокутника, не співпадаючих з граничною поверхнею, виконувалися умови загасання збурень, обумовлених концентрацією напружень навколо волокон. Постановка задачі здійснюється аналогічно постановці для двох послідовно розміщених волокон у нескінченній матриці при стисканні вздовж напрямку розташування волокон [11] (рис. 1, б). При цьому граничні умови на вільній поверхні є однорідним умовами у напруженнях. Також мають місце умови згасання "на нескінченності" при $x_{1} \rightarrow \pm \infty, x_{2} \rightarrow-\infty$. "На нескінченності" композит навантажений у напрямі $O x_{1}$ стискаючим навантаженням постійної інтенсивності $P$. Навантаження вважається "мертвим", що забезпечує виконання достатніх умов застосування статичного методу ТЛТСДТ [7].

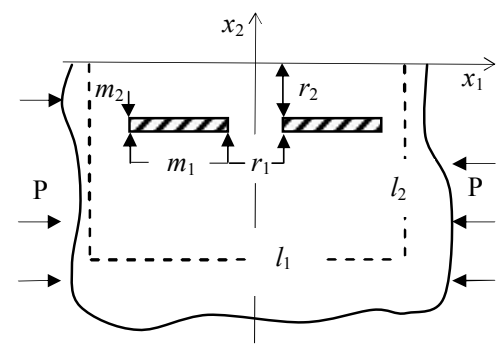

a)

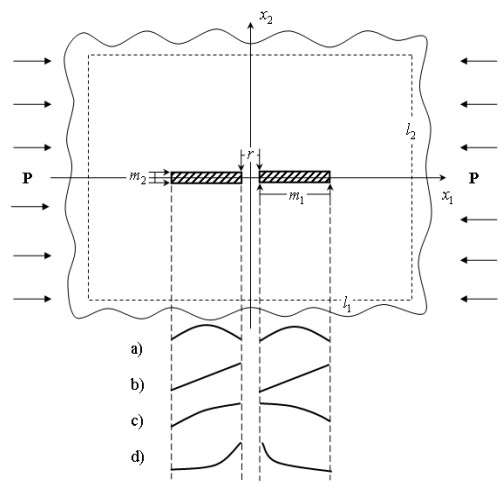

б)

Рис.1 - Розрахункові моделі для дослідження втрати стійкості у приповерхневих волокнах (а) та внутрішній структурі (б) слабкоармованих КМ

Дослідження докритичного стану виконується у рамках класичної лінійної теорії пружності ізотропного тіла. Задача стійкості при застосуванні статичного методу зводиться до узагальненої задачі на власні значення, у якій мінімальне власне значення $\lambda$ відповідає критичному навантаженню, а відповідна власна функція $\boldsymbol{u}=\left(u_{1}, u_{2}\right)$ визначає фрорму втрати стійкості. 
Початковий стан із урахуванням симетрії навантаження визначаємо із наступних основних співвідношень лінійної теорії пружності для області $\bar{\Omega}=\left\{\left(x_{1}, x_{2}\right) \mid 0 \leq x_{1} \leq l_{1} / 2 ;-l_{2} \leq x_{2} \leq 0\right\}$ :

- рівняння рівноваги

$$
\sigma_{i j, i}^{0}=0 \quad x \subset \bar{\Omega}
$$

- граничні умови

$$
\begin{aligned}
& \sigma_{12}^{0}=0 \wedge \sigma_{22}^{0}=0,\left(0 \leq x_{1} \leq l_{1} / 2\right) \wedge\left(x_{2}=0\right) \\
& \sigma_{12}^{0}=0 \wedge u_{2}^{0}=0,\left(0 \leq x_{1} \leq l_{1}, 2\right) \wedge\left(x_{2}=-l_{2}\right) ; \\
& u_{1}^{0}=0 \wedge \sigma_{12}^{0}=0,\left(x_{1}=0\right) \wedge\left(-l_{2} \leq x_{2} \leq 0\right) ; \\
& \sigma_{11}^{0}=P \wedge \sigma_{12}^{0}=0,\left(x_{1}=l_{1} / 2\right) \wedge\left(-l_{2} \leq x_{2} \leq 0\right) ;
\end{aligned}
$$

- умови ідеального контакту на границі між компонентами КМ

$$
\left[n_{i} \sigma_{i j}^{0}\right]=0,\left[u_{i}^{0}\right]=0 ;
$$

- $\quad$ співвідношення між компонентами напружень $\sigma_{i j}^{0}$, деформацій $\varepsilon_{i j}^{0}$ и переміщень $u_{i}^{0}$ у межах компонента КМ

$$
\sigma_{i j}^{0}=\delta_{i j} A_{i k} \varepsilon_{k k}^{0}+2\left(1-\delta_{i j}\right) G \varepsilon_{i j}^{0}, \quad \varepsilon_{i j}^{0}=\frac{1}{2}\left(u_{i, j}^{0}+u_{j, i}^{0}\right), i \neq j,
$$

де

$$
A_{11}=A_{22}=\frac{E(1-v)}{(1+v)(1-2 v)}, A_{12}=\frac{E v}{(1+v)(1-2 v)}, G=\frac{E}{2(1+v)} .
$$

Тут $A_{i j}, E, G, v$ - приведені модулі пружності, модуль Юнга, модуль зсуву та коефіцієнт Пуассона компоненту КМ відповідно.

Основні співвідношення тривимірної лінеаризованої теорії стійкості для визначення критичних параметрів стійкості КМ мають наступний вигляд:

- рівняння рівноваги у збуреннях

$$
\left(\sigma_{m i}+\lambda \sigma_{j i}^{0} u_{m, i}\right)_{, j}=0, x \in \bar{\Omega} ;
$$

- граничні умови 


$$
\begin{gathered}
\sigma_{m 2}=0,\left(0 \leq x_{1} \leq l_{1} / 2\right) \wedge x_{2}=0 ; \\
\left(\sigma_{12}+\lambda \sigma_{22}^{0} u_{1,2}\right)=0 \wedge u_{2}=0,\left(0 \leq x_{1} \leq l_{1} / 2\right) \wedge x_{2}=-l_{2} ; \\
u_{1}=0 \wedge \sigma_{12}+\lambda\left(P u_{2,1}+\sigma_{12}^{0} u_{2,2}\right)=0,\left(x_{1}=0\right) \wedge\left(-l_{2} \leq x_{2} \leq 0\right) ; \\
\sigma_{m 1}+\lambda\left(P u_{m, 1}+\sigma_{12}^{0} u_{m, 2}\right)=0,\left(x_{1}=l_{1} / 2\right) \wedge\left(-l_{2} \leq x_{2} \leq 0\right) ;
\end{gathered}
$$

- умови ідеального контакту на границі між компонентами КМ

$$
\left[n_{i}\left(\sigma_{m i}+\lambda \sigma_{i j}^{0} u_{m, \mathrm{j}}\right)\right]=0,\left[u_{i}\right]=0 \text {. }
$$

Співвідношення між збуреннями напружень $\sigma_{i j}$, дефрормацій $\varepsilon_{i j}$ i переміщень $u_{i}$ у межах компонента КМ мають вигляд (4).

Позначення в (1) - (8) є загальноприйнятим, індекси змінюються від 1 до 2 ( $\wedge, \vee-$ знаки логічного множення и додавання). Верхнім індексом “0” позначені компоненти напружень и переміщень для докритичного стану. Індекс, який позначає належність до компоненти КМ, для зручності не застосовується. У співвідношеннях (3), (8) $n_{i}$ - орти зовнішньої нормалі до поверхні, $[f(x)]=f(x-0)-f(x+0)$ - стрибок фрункціï $f(x)$.

Критичне навантаження визначається із співвідношення

$$
p_{\kappa p}=\min |\lambda| P
$$

де $\min |\lambda|$ - мінімальне за модулем власне значення задачі (6) - (8); $P$ - інтенсивність зовнішнього навантаження.

Числовий розв'язок. Задачі (1) - (5), (6) - (8) розв'язані методом сіток із застосуванням концепції базової схеми [2]. Для розв'язуваня дискретних задач застосовані ефективні числові методи відповідно до методики, представленої в [5, 12]. У даному випадку алгебраїчна задача визначення початкового стану розв'язувалася прямим методом Холецького, а після згущення різницевої сітки застосовувався ітераційний метод спряжених градієнтів [5, 17]. При цьому розв'язок, отриманий методом Холецького, інтерполювався і приймався як початкове наближення щодо початкового стану для розв'язування дискретної задачі стійкості на власні значення методом ітерування підпростору [5, 17].

Аналіз числових результатів. Результати отримані для розрахункової моделі, представленої на рис. 1,а. Для порівняльного аналізу застосовані результатиі [11] для розрахункової моделі, поданої на рис. 1,б. Розрахунки були проведені для наступних механічних та гео- 
метричних характеристик КМ (індекс "а" відноситься до волокна, індекс " $m$ "- до матриці): відношення модулів Юнга волокна і матриці $E_{a} E_{m}^{-1}=100$; коефіцієнти Пуассона $v_{a}=v_{m}=0,3$; коефріцієнт фрорми волокон $m_{1} / m_{2}=10$; безрозмірна відстань $r_{1}^{*}=r_{1} / m_{1}$ між волокнами приймала значення 0 ; 02; 0,2; 2,0; безрозмірна відстань $r_{2}^{*}=r_{2} / m_{1}$ між волокнами і вільною поверхнею приймала значення $0 ; 0,2 ; 0,5 ; 2,0$.

На рис. 2 показано розподілення безрозмірних збурень переміщень $u_{2}^{*}\left(x_{1}^{*}\right)=u_{2}\left(x_{1}^{*}\right) / u_{2}^{\max }$ (форми втрати стійкості) для вказаних значень відстані $r_{1}^{*}$ між волокнами та відстані $r_{2}^{*}$ волокон до вільної поверхні матеріалу. Із урахуванням симетрії відносно осі $O x_{2}$ отриманих значень для розподілення переміщень у докритичному стані та збурень переміщень графрічна інформація наведена для одного волокна, розташованого у області $0 \leq x_{1} \leq r_{1}+3 / 2 m_{1}$. На рис. 3 , відповідно до результатів [11], показано розподілення збурень переміщень $u_{2}^{*}\left(x_{1}^{*}\right)$ для випадку двох волокон у нескінченній матриці для значень $r_{1}^{*}=0,001 \mathrm{i}$ $r_{1}^{*}=1,0$ відстані між волокнами. Граффіки побудовані для горизонтальних перерізів волокон: $x_{2}=-r_{2},-\left(r_{2}+m_{2} / 2\right),-\left(r_{2}+m_{2}\right)$ для області $\bar{\Omega}=\left\{\left(x_{1}, x_{2}\right) \mid 0 \leq x_{1} \leq r_{1}+3 / 2 m_{1} ;-\left(r_{2}+m_{2}\right) \leq x_{2} \leq-r_{2}\right\}$. Відповідні криві на рисунках позначені як 1, 2, 3. У наведених вище виразах $u_{2}^{\max }$ - максимальне значення збурення переміщень у волокні для вказаній області, $x_{1}^{*}=\left(x_{1} / m_{1}\right)$ - безрозмірна координата.

Як зазначено в [5] для випадку двох послідовно розміщених коротких волокон у нескінченній матриці (розрахункова модель на рис. 1, б) втрата стійкості у внутрішній структурі КМ може відбуватись відповідно до наступних форм втрати стійкості. Згинальна фрорма втрати стійкості а) відповідає випадку, коли кожний армуючий елемент втрачає стійкість як би майже без взаємодії з іншим армуючим елементом. Форма втрати стійкості b) відповідає випадку, коли виникає майже жорсткий поворот кожного волокна; такий випадок реалізується для досить жорсткого матеріалу волокон, коли матриця не забезпечує належної підтримувальної дії і при втраті стійкості на торцях як би утворюється "шарнір", близький до пластичного шарніру. Схема с) відповідає випадку, коли два волокна втрачають стійкість як би по "одній згинальній фрормі"(загальна згинальна форма втрати стійкості). Схема с) відповідає випадку, коли два волокна втрачають стійкість як би по "одній згинальній фрормі"(загальна згинальна фрорма втрати стійкості). Схема d) відпо- 
відає випадку, коли два волокна втрачають стійкість як би при порівняно жорсткому взаємному повороті сусідніх волокон з деяким згином; такий випадок реалізується для досить жорсткого матеріалу волокон, коли матриця між волокнами не забезпечує належної підтримувальної дії i при втраті стійкості між волокнами як би виникає "шарнір", близький до пластичного шарніру.

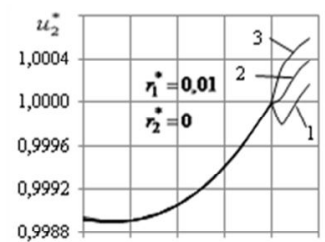

$\begin{array}{llllll}0,01 & 0,26 & 0,51 & 0,76 & 1,01 & x_{1}^{*}\end{array}$
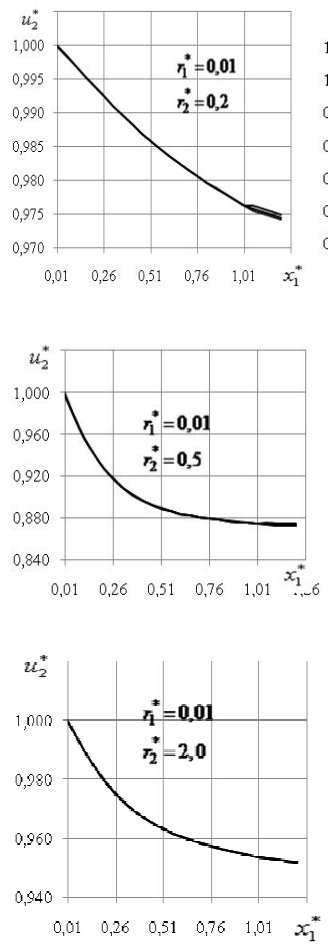
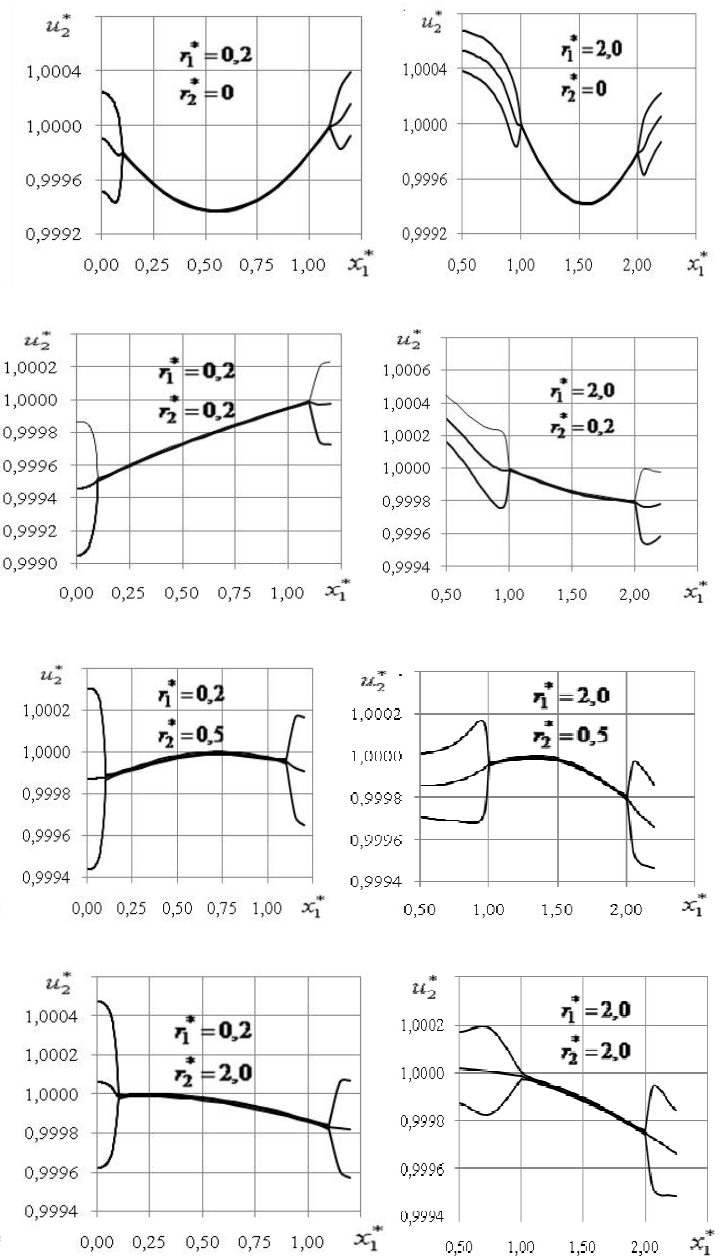

Рис. 2 - Розподілення збурень переміщень $u_{2}^{*}\left(x_{1}^{*}\right)$ (форми втрати стійкості) в залежності від відстані $r_{1}^{*}$ між волокнами та відстані $r_{2}^{*}$ волокон до вільної поверхні 


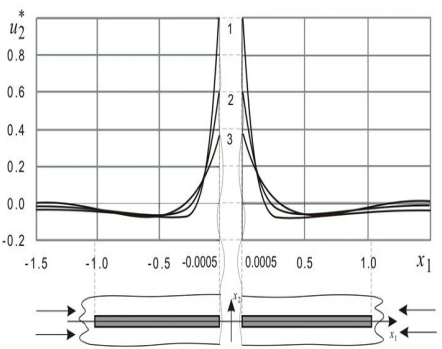

a)

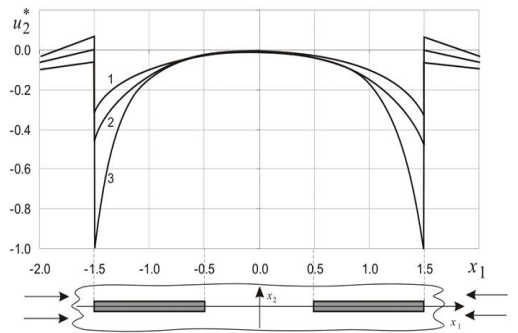

б)

Рис. 3 - Розподілення збурень переміщень $u_{2}^{*}\left(x_{1}^{*}\right)$ (форми втрати стійкості) для випадку двох волокон у нескінченній матриці:

а) - для значення $r_{1}^{*}=0,001$ відстані між волокнами;

б) - для значення $r_{1}^{*}=1,0$

У [11] встановлено, що при зменшенні відстані між волокнами послідовно реалізуються форми втрати стійкості, які близькі до передбачених форм втрати стійкості с) (рис. 3, б) - "загальна згинальна форма втрати стійкості” і форми d) (рис. 3, а) - “взаємний поворот із вигином”. Аналогічний результат спостерігається для віддалених від вільної поверхні волокон. На рис. 2 ці форми відповідають графікам для значень $\left(r_{1}^{*}=2,0 ; r_{2}^{*}=2,0\right)$ i $\left(r_{1}^{*}=0,02 ; r_{2}^{*}=2,0\right)$. При наближенні до вільної поверхні реалізуються форми втрата стійкості, які відповідають жорсткому повороту волокон з подальшою зміною напрямку згину відносно осі волокна та зміною напрямку повороту відносно осі, яка проходить через середину волокон нормально до вільної поверхні КМ (рис. 2).

Висновки. Отримані результати дозволяють зробити наступні висновки.

1. Під дією стискаючого навантаження в КМ, армованому приповерхневими короткими волокнами, виникає несиметричний докритичний напружено-деформівний стан як відносно власної осі волокон, так і відносно осі, яка проходить через середину волокон нормально до вільної поверхні КМ. Це призводить до початкового викривлення волокон, яке може стати причиною руйнування КМ, коли величина докритичної деформації перевищуватиме межу міцності матеріалу у структурі КМ.

2. Форми втрати стійкості армуючих волокон залежать від їх розташування у матриці, що певним чином може впливати на механізми руйнування, пов'язані із втратою стійкості у структурі КМ. Для волокон, розташованих на поверхні має місце згинальна форма втрати стійкості, яка суттєво не змінюється при зближенні волокон. При віддаленні від вільної поверхні мають місце втрата стійкості у формі повороту із згином та жорсткого взаємного повороту волокон. При зміні відстані між волокнами змінюється напрямок повороту та згину. Для віддалених від 
вільної поверхні волокон при їх зближенні реалізуються ті самі форми, що і для волокон у нескінченній матриці.

\section{БІБЛІОГРАФІЧНІ ПОСИЛАННЯ}

1. Быстров В.М., Декрет В.А., Зеленский В.С. Численное исследование устойчивости слоистого композитного материала при сжатии поверхностной нагрузкой // Пробл. обчисл. механіки і міцності конструкцій: зб. наук. праць. 2018. Вип. 28. С. 2333.

2. Григоренко Я.М., Шевченко Ю.В., Василенко А.Т. и др. Численные методы. Механика композитов: В 12-и т. / Под общей ред. А.Н. Гузя. Т.11. К.: «А.С.К.». 2002. $448 \mathrm{c}$.

3. Гузь А.Н. Основы трехмерной теории устойчивости деформируемых тел. К.: Вища школа. 1986. 512 с.

4. Гузь А.Н. Основы механики разрушения композитов при сжатии: В 2-х т. (Т.1. Разрушение в структуре материала. 592 с. Т. 2. Родственные механизмы разрушения. 736 с.). К.: “ЛИТЕРА", 2008.

5. Гузь А.Н., Декрет В.А. Модель коротких волокон в теории устойчивости композитов. Saarbrücken : LAP Lambert acad. publ., 2015. 315 c.

6. Декрет В. А., Зеленский В. С., Быстров В. М. Устойчивость композитного материала, слабоармированного короткими волокнами // Пробл. обчисл. механіки і міцності конструкцій: зб. наук. праць. 2016. Вип. 25. С. 27-39.

7. Guz A.N. Fundamentals of the Three-Dimensional Theory of Stability of Deformable Bodies. Berlin Heidelberg New York: Springer-Verlag, 1999. 555 p.

8. Guz A.N. Nonclassical Problems of Fracture/Failure Mechanics: On the Occasion of the 50th Anniversary of Research (Review). II. // International Applied Mechanics. 2019. Vol. 55. No 3. P. 239-295.

9. Guz A.N., Dekret V.A. On Two Models in the Three-Dimensional Theory of Stability of Composite Materials // Int. Appl. Mech. 2008. Vol. 44. No 8. P. 839-854.

10. Guz A.N., Dekret V.A. Finite-Fiber Model in the Three-Dimensional Theory of Stability of Composites // Int. Appl. Mech. 2016. Vol. 52. No 1. P. 1-48.

11. Guz A.N., Dekret V.A., Kokhanenko Yu. V. Two-dimensional Stability Problem for Interacting Short Fiber Model in Composite: In-line Arrangement // Int. Appl. Mech. 2004. Vol. 40. No 9. P. 994-1001.

12. Guz A.N., Kokhanenko Yu. V. Numerical Solution of Three-Dimensional Stability Problems for Elastic body // Int. Appl. Mech. 2001. Vol. 37. No 11. P. 1369-1399.

13. Guz A.N., Lapusta Yu. N. Three-Dimensional Problems of the Near-surface Instability of Fiber Composites in Compression (Model of Piecewise Uniform Medium) (Survey) // Int. Appl. Mech. 1999. Vol. 35. No 7. P. 641-670.

14. Dekret V.A. Near-Surface Instability of Composite Materials Weakly Reinforced with Short Fibers // Int. Appl. Mech. 2008. Vol. 44. No 6. P. 609-625.

15. Dekret V.A., Zelenskii V.S., Bystrov V.M. Numerical Analysis of Stability of a Laminated Composite with Compressed Reinforcement Plies // Int. Appl. Mech. 2015. Vol 51. No 5. P. 561-566.

16. Harich J., Lapusta Y., Wagner W. 3D FE-modeling of surface and anisotropy effects during micro-buckling in fiber composites // Compos. Struct. 2009. Vol. 89. No 4. P. $551-555$.

17. Pissanetzky S. Sparse Matrix Technology. London: Academic Press, 1984. 321 p. 
В. М. Быстров, канд. фриз.-мат. наук, В. А. Декрет, д-р фриз.-мат. наук, В. С. Зеленский, канд. физ.-мат. наук

\title{
ПОТЕРЯ УСТОЙЧИВОСТИ КОМПОЗИТНОГО МАТЕРИАЛА, СЛАБОАРМИРОВАННОГО ПРИПОВЕРХНОСТНЫМИ КОРОТКИМИ ВОЛОКНАМИ
}

\begin{abstract}
С использованием основных соотношений трехмерной линеаризованной теории устойчивости в рамках модели кусочно-однородной среды исследована потеря устойчивости композитного материала, слабоармированного короткими волокнами вблизи свободной плоской граничной поверхности. Установлена зависимость форм потери устойчивости в структуре композитного материала от расположения волокон относительно свободной поверхности и от расстояния между соседними волокнами. Для численного решения задачи использован метод сеток на основе модифицированного вариационно-разностного подхода.
\end{abstract}

Ключевые слова: приповерхностные короткие волокна; фоорма потери устойчивости; кусочно-однородная модель; трехмерная линеаризированная теория устойчивости; численный подход.

UDC 539.3

$$
\begin{gathered}
\text { V. M. Bystrov, PhD (Phys.-Math.), V. A. Dekret, Dr. Sci. (Phys.-Math.), } \\
\text { V. S. Zelenskii, PhD (Phys.-Math.) }
\end{gathered}
$$

\section{LOSS OF STABILITY OF THE COMPOSITE MATERIAL WEAKLY REINFORCED BY NEAR-SURFACE SHORT FIBRES}

The stability loss of a composite material weakly reinforced with short fibers near a free flat boundary surface is investigated using the basic relations of the three-dimensional linearized theory of stability within the framework of the model of a piecewise homogeneous medium. The dependence of the buckling modes in the structure of the composite material on the location of the fibers relative to the free surface and on the distance between adjacent fibers is established.

Keywords: near-surface short fibers, buckling modes, piecewise homogeneous model, three-dimensional linearized theory of stability, numerical approach.

One of the possible mechanisms of fracture of unidirectional composite materials (CM) during compression along the direction of reinforcement is the loss of stability of the reinforcing layers and fibers. This mechanism may be in the nature of loss of stability in the internal structure of the $\mathrm{CM}$ or nearsurface loss of stability in the structure of the CM with buckling modes subsiding away from the surface of the CM. The study of near-surface buckling is carried out in two directions. The first direction concerns the study of the loss of stability in the material structure at the free boundary surface, the second - at the loaded surface. As a rule, the phenomenon of near-surface instability precedes internal instability. In this regard, its study makes it possible to establish the minimum value of the critical load parameters at which a loss of bearing capacity can occur in the near-surface layers of the composite material for the first case, or in the layers near the loaded surface in the 
second case. In the study of this problem, it is customary to model composite materials with a semi-bounded body of regular or irregular structure with the subsequent satisfaction of the attenuation conditions of the factors under study at infinity. One of the most accurate approaches when considering this problem is the application of the three-dimensional linearized theory of stability of deformable bodies (TLTSDT) $[3,7]$ within the model of a piecewise homogeneous medium. A review of the corresponding results for $\mathrm{CM}$ reinforced with continuous components under compression parallel to the free surface is presented in $[4,13]$. Some results related to the loss of stability of $\mathrm{CM}$ at a loaded surface are given in $[1,15]$. The results of studying the stability of CMs reinforced with short fibers based on the "short fibers" model are presented in [5, 9-11]. The phenomenon of near-surface buckling of a composite material weakly reinforced with short fibers near the free boundary surface is considered in [14] for the model of one near-surface fiber in a semi-infinite matrix. In this paper, we consider the case of two interacting near-surface fibers in a weakly reinforced CM under longitudinal compression. For the numerical solution of the problems under consideration, the grid method is used based on a modified variational - difference approach [2, 12].

The paper considers the case when the $\mathrm{CM}$ is considered weakly reinforced and has an irregular structure. This assumption allows us to consider the design scheme for in - line arrangement of two near-surface fibers in a semi-infinite matrix. One of the sides of the corresponding computational domain coincides with the free boundary surface. The boundary conditions on the free surface are homogeneous conditions in stresses. The conditions of attenuation "at infinity" also take place at $x_{1} \rightarrow \pm \infty, x_{2} \rightarrow-\infty$. "At infinity" the composite is loaded in the $O x_{1}$ direction by a compressive load of constant intensity $P$. Based on the assumption that the matrix and fibers are quite stiff, the second variant of the theory of small subcritical deformations $[3,7]$ is used in the study of stability. The subcritical state can be determined by solving the problem of linear elasticity for piecewise homogeneous bodies. The surface load is considered "dead», which ensures that enough conditions for the applicability of the static method are met [7]. When using this method, the stability problem is reduced to a generalized eigenvalue problem, in which the minimum eigenvalue $\lambda$ determines the critical load, and the corresponding eigenfunction $\boldsymbol{u}=\left(u_{1}, u_{2}\right)$ describes the buckling mode.

The results obtained in this work lead to the following conclusion. The buckling modes of reinforcing fibers depend on their location in the matrix, which in a certain way can affect the mechanisms of fracture associated with the loss of stability in the CM structure. For fibers located on the surface, there is a bending form of buckling, which does not change significantly when the fibers approach. When moving away from the free surface, there is a loss of stability in the form of rotation with bending and rigid mutual rotation of the fibers. When the distance between the fibers changes, the direction of rotation and bending changes. For fibers distant from the free surface, when they approach, the same shapes are realized as for fibers in an infinite matrix. 


\section{REFERENCES}

1. Bystrov V.M., Dekret V.A., Zelenskii V.S. Numerical study of stability of layered composite material compressed by surface load // Problems of the computational mechanics of strength and structures. 2018. Vol. 28. P. 23-33. (in Russian).

2. Grygorenko Ya.M., Shevchenko Yu. N., Vasilenko A. T. et al. Computaional methods. Mechanics of composites: In 12 volumes / Editor-in-Chief A.N. Guz. Vol.11. Kiev: A.S.K., 2002. 448 p. (in Russian).

3. Guz A. N. Fundamentals of three-dimensional theory of stability of deformable bodies. Kyiv: Vysha Shkola, 1986. 512 p. (in Russian).

4. Guz A.N. Fundamentals of the compressive fracture mechanics of composites. Edition in 2 volumes (Vol. 1. Fracture in structure of materials. Vol. 2. Related mechanisms of fracture.). Kyiv: LITERA, 2008. (in Russian)

5. Guz A.N., Dekret V. A. Model of short fibres in the theory of stability of composites. LAPLAMBERT Academic Publishing, 2015. 315 p. (in Russian).

6. Dekret V.A., Zelenskii V.S., Bystrov V.M. Stability of the composite material weakly reinforced by short fibres // Problems of the computational mechanics of strength and structures. 2016. Vol. 25. P. 27-39. (in Russian).

7. Guz A.N. Fundamentals of the Three-Dimensional Theory of Stability of Deformable Bodies. Berlin Heidelberg New York: Springer-Verlag, 1999. 555p.

8. Guz A.N. Nonclassical Problems of Fracture/Failure Mechanics: On the Occasion of the 50th Anniversary of Research (Review). II. // Int. Appl. Mech. 2019. Vol. 55. No 3, P. 239-295.

9. Guz A.N., Dekret V.A. On Two Models in the Three-Dimensional Theory of Stability of Composite Materials // Int. Appl. Mech. 2008. Vol. 44. No 8, P. 839-854.

10. Guz A.N., Dekret V.A. Finite-Fiber Model in the Three-Dimensional Theory of Stability of Composites // International Applied Mechanics. 2016. Vol. 52. No 1. pp. 1-48.

11. Guz A.N., Dekret V.A., Kokhanenko Yu. V. Two-dimensional Stability Problem for Interacting Short Fiber Model in Composite: In-line Arrangement // Int. Appl. Mech. 2004. Vol. 40. No 9. P. 994-1001.

12. Guz A.N., Kokhanenko Yu. V. Numerical Solution of Three-Dimensional Stability Problems for Elastic body // Int. Appl. Mech. 2001. Vol. 37. No 11. P. 1369-1399.

13. Guz A.N., Lapusta Yu. N. Three-Dimensional Problems of the Near-surface Instability of Fiber Composites in Compression (Model of Piecewise Uniform Medium) (Survey) // // Int. Appl. Mech. 1999. Vol. 35. No 7. P. 641-670.

14. Dekret V.A. Near-Surface Instability of Composite Materials Weakly Reinforced with Short Fibers // Int. Appl. Mech. 2008. Vol. 44. No 6, P. 609-625.

15. Dekret V.A., Zelenskii V.S., Bystrov V.M. Numerical Analysis of Stability of a Laminated Composite with Compressed Reinforcement Plies // Int. Appl. Mech. 2015. Vol 51. No 5. P. 561-566.

16. Harich J., Lapusta Y., Wagner W. 3D FE-modeling of surface and anisotropy effects during micro-buckling in fiber composites // Compos. Struct. 2009. Vol. 89. No 4. P. 551-555.

17. Pissanetzky S. Sparse Matrix Technology. London: Academic Press, 1984. $321 \mathrm{p}$.

Інститут механіки ім. С. П. Тимошенка

НАН України,

Київ, Україна

Надійшла до редколегії 12.05.2020 